\title{
Mixture of Toxic Metals and Volatile Organic Compounds in a River Induces Cytotoxicity
}

\author{
Andrés Estrada, ${ }^{1}$ Wendy A. García, ${ }^{1}$ Edith Chavez ${ }^{\mathbb{D}},{ }^{1}$ Rosalia Castelan ${ }^{\mathbb{D}},{ }^{1}$ María T. Zayas, ${ }^{2}$ \\ Samuel Treviño $\mathbb{D}^{3},{ }^{3}$ Alfonso Diaz $\mathbb{D},^{3}$ and Anabella Handal $\mathbb{I D}^{1}$ \\ ${ }^{1}$ Instituto de Ciencias, BUAP, Puebla, Mexico \\ ${ }^{2}$ Centro de Química-ICUAP, BUAP, Puebla, Mexico \\ ${ }^{3}$ Facultad de Ciencias Químicas, BUAP, Puebla, Mexico
}

Correspondence should be addressed to Alfonso Diaz; alfonso.diaz@correo.buap.mx and Anabella Handal; anabella.handal@correo.buap.mx

Received 13 December 2021; Accepted 31 January 2022; Published 7 March 2022

Academic Editor: Liviu Mitu

Copyright (c) 2022 Andrés Estrada et al. This is an open access article distributed under the Creative Commons Attribution License, which permits unrestricted use, distribution, and reproduction in any medium, provided the original work is properly cited.

\begin{abstract}
Pollution of aquatic ecosystems due to toxic mixtures is a worldwide problem associated with the increase of wastewater discharges that causes problems to human health and biodiversity. This study aims to evaluate the cytotoxic potential of water from the Atoyac River. Meristems of Allium cepa L. were exposed to water samples from the Atoyac River with different concentrations for 120 hours. Pearson correlation was used to investigate the relationship between contaminants and cytotoxicity. The results corroborated the cytotoxic effect of the mixture of agents such as toxic metals and volatile organic compounds found in all river sampling sites. The Allium cepa test showed decreased mitotic alterations in prophase and metaphase indices. There was a strong negative association between the concentration of toxic metals and volatile organic compounds and the cytotoxic effect. The observations of cytotoxic effects show that the contaminant mixture contains aneugenic agents which prevent the synthesis and fixation of fibers of the mitotic spindle to the kinetochore, which prevents the displacement of the chromosomes. This study shows the need to study the effects at the cellular and molecular level in heavily polluted rivers to prevent negative effects on exposed ecosystems and populations.
\end{abstract}

\section{Introduction}

Rivers are one of the main sources of drinking water for humanity [1]; however, its pollution has been increasing in developed countries and has become a global environmental problem. It is estimated that, of the 500 major rivers in the world, $50 \%$ are polluted [2]. The main sources that have contributed to river pollution are agricultural runoff and industrial and urban wastewater discharges [3], which contain great amounts of waste such as fertilizers, pesticides, toxic metals, and organic and inorganic compounds [4], which upon reaching the aquatic ecosystem produce toxic pollutant mixtures [5] with high cytotoxic potential capable of inducing biodiversity changes and people mutations and diseases such as cancer [4-7].

Few studies have been conducted globally to determine the cytotoxic potential of complex mixtures of toxic metals
(TM) and volatile organic compounds (VOCs) in aquatic ecosystems such as rivers $[8,9]$, and most have focused on evaluating the cytotoxic effects of mixtures of TM and VOCs in occupational $[10,11]$ and urban environments [12]. Therefore, there is a need to conduct cytotoxic assessment studies using biomodels that explain the short- and longterm health risks of organisms exposed to aquatic environments influenced by contaminant mixtures of TM and VOCs that are potentially carcinogenic.

The objective of this research was to evaluate the effect of the contaminant mixture of TM and VOCs present in the water of the Atoyac River and its correlation on the mitotic index (MI) and phase index (PI) in the cell population with respect to the concentration of contaminants in different sampling zones using the biomodel Allium cepa $\mathrm{L}$., which is a model recognized as one of the best indicators to evaluate the cytotoxic potential of environmental pollutants due to its 
high sensitivity, good correlation with other test systems, easy handling, low cost, and large chromosomes [13]. The study will serve as a proposal to consider cytotoxic evaluation as part of the integral characterization of water quality in contaminated water bodies and will help provide information to complement the Official Standards to avoid health risks to which the inhabitants of river areas with strong environmental degradation could potentially be exposed.

\section{Materials and Methods}

2.1. Sample Collection. Surface water samples were collected in 3 zones along the Atoyac River through the municipality of San Martin Texmelucan, Puebla (Figure 1). San Martin Texmelucan (geographical coordinates: $19^{\circ} 17^{\prime} 07^{\prime \prime} \mathrm{N}$ $98^{\circ} 26^{\prime} 01^{\prime \prime} \mathrm{W}$ ), which is in the western part of the PueblaTlaxcala Valley, has a population of 152,052 inhabitants which are distributed in a territorial extension of $71.45 \mathrm{~km}^{2}$ [14]. The collection areas were chosen according to the anthropogenic characteristics of the site (Table 1). Samples were collected during the rainy season (April 2019), which begins in the municipality of San Martín Texmelucan in April and ends in October with a rainfall range of $700-800 \mathrm{~mm}$ [15]. Therefore, the area is classified as torrentially rainy according to the criteria of State Weather Agency [16].

For taking the samples, the guidelines of the Mexican Standard NMX-AA-121/1-SCFI-2008 [17] were followed. A volume of $2 \mathrm{~L}$ was collected from each area in properly sterilized wide-mouth polyethylene containers. The containers with the samples were stored under refrigeration at approximately $5^{\circ} \mathrm{C}$ in a cooler and transported immediately to the laboratory to be used the same day for physicochemical analysis and bioassays.

2.2. Allium cepa Test. The Allium cepa test was performed according to Fiskesjö (1985) [18]. Allium cepa L. bulbs of similar diameters were purchased in a local market in the city of Puebla. All tests were carried out on a single batch of bulbs to avoid variations in the various stages of the test. Before starting the tests, the dry root base of the bulbs was eliminated, taking care of the taproot. With the river water, three solutions were prepared for each sampling zone at different concentrations in volume percentage, which were $25 \%, 50 \%$, and $100 \%$, and a control solution with purified water for each sampling zone. The bulbs were randomly placed in the solution for 120 hours. The experiment was performed in triplicate. At the end of the treatment for cytotoxic evaluation, the mitotic index (MI) (number of cells in meristem of Allium cepa L. in mitosis) and phase indices, prophase index (PI) (number of cells in prophase stage), metaphase index (MeI) (number of cells in metaphase stages), anaphase index (AI) (number of cells in anaphase stages), and telophase index (TI) (number of cells in telophase stages), were determined (Figure 2). The total number of cells analysed from each experimental group was 1000 and compared with their control group. Mitotic index (MI) and phase index (PI) were calculated by counting 1000 cells per concentration:

$$
\begin{aligned}
\mathrm{IM} & =\frac{\mathrm{N} \text { of dividing cells }}{\mathrm{N} \text { of cells counted }} \times 100, \\
\mathrm{IF} & =\frac{\mathrm{N} \text { of cells of each phase }}{\mathrm{N} \text { of cells counted }} \times 100 .
\end{aligned}
$$

2.3. Physicochemical Analysis. Determining some physicochemical parameters of water samples helps us to better understand the relationship with the results, since water quality can affect metabolism in biological systems. In the present investigation, $\mathrm{pH}$ parameters were determined in situ by using a pH meter (pHep ${ }^{\circledR}$ model HI 98107), electrical conductivity was determined by using a portable meter (CONDUCTRONIC model PC18), dissolved oxygen was calculated using the Winkler method with a Hanna ${ }^{\top}$ HI 3810 Dissolved Oxygen Test Kit, and temperature was determined by using a glass thermometer with a mercury column scale from $-10^{\circ} \mathrm{C}$ to $110^{\circ} \mathrm{C}$ (Celsius brand).

Water quality characterization was complemented with laboratory tests to determine the following parameters: chemical oxygen demand (COD), which was determined with a Spectroquant kit in the $25-1500 \mathrm{mgL}^{-1}$ range. The test is based on the method for determining chromium III and chromium sulfuric acid oxidation, biochemical oxygen demand $\left(\mathrm{BOD}_{5}\right)$, turbidity, volatile organic compounds, and toxic metals. Turbidity measurement was carried out with the Nova 60 Spectroquant photometer using a $10 \mathrm{ml}$ volume of the sample, without any treatment or filtering, with a $50 \mathrm{~mm}$ thick rectangular measuring cell. The determination of VOCs was carried out by gas chromatography coupled to a mass spectrometer, under the guidelines of NMX-AA-103SCFI-2006 [19], for which a gas chromatograph with a capillary injection port and mass selective detector was used. The measurement of TM was carried out in accordance with NMX-AA-051-SCFI-2006 [20] using a flame atomization atomic absorption spectrophotometer with a double beam monochromator, light source, and photomultiplier detector adjustable to the wavelength intervals of the analytes to be quantified.

2.4. Statistical Analysis. Comparison was made between treatments and their respective control groups in each study area. Quantitative data were analysed by the ANOVA method to compare several groups in a quantitative variable. The results were plotted as the mean\pm standard error of the mean (SEM). Post hoc analysis was done by Tukey's test, $p \leq 0.05$. The correlation between the concentration of arsenic, cadmium, chromium, copper, mercury, benzene, chloroform, and tetrachloroethylene with mitotic index was determined by calculating Pearson correlation coefficients with $p \leq 0.05$ significance. Statistical treatments of the data were carried out using Minitab 19 software. 


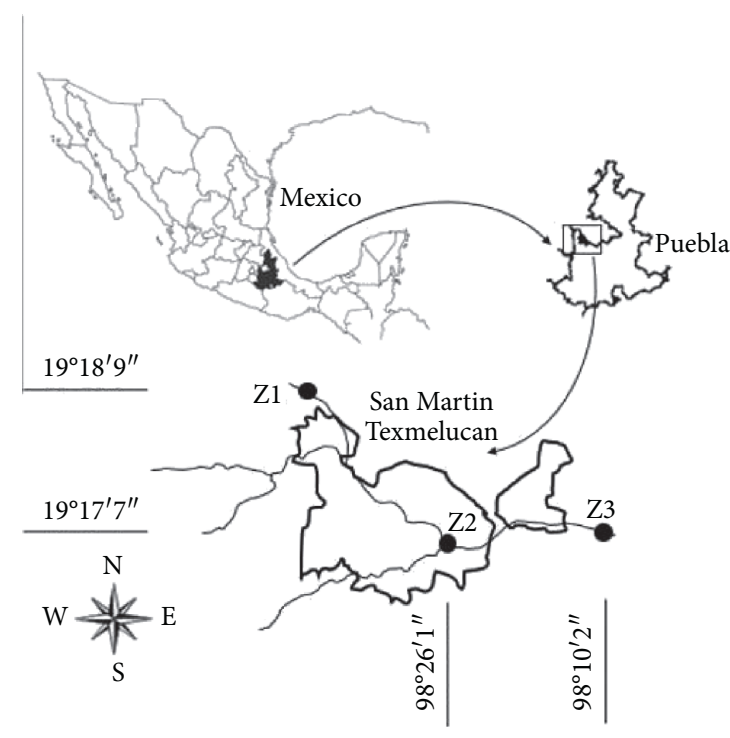

FIGURE 1: Location of sampling points in the study area.

TABle 1: Characteristics of sampling areas.

\begin{tabular}{|c|c|c|c|}
\hline Zone & Locality & Coordinates & Characteristics \\
\hline 1 & San Cristobal Tepatlaxco & $\begin{array}{l}19^{\circ} 17^{\prime} 54.6^{\prime \prime} \mathrm{N} \\
98^{\circ} 27^{\prime} 23.0^{\prime \prime} \\
\mathrm{W}\end{array}$ & $\begin{array}{c}\text { Agroforestry area (corn and wheat crops), livestock activities (bovine cattle), 12,045 } \\
\text { inhabitants, } 3 \text { small industries (processing of dairy products), and } 290 \text { commercial } \\
\text { establishments }\end{array}$ \\
\hline 2 & $\begin{array}{l}\text { San Martin Texmelucan } \\
\text { Labastida }\end{array}$ & $\begin{array}{l}19^{\circ} 16^{\prime} 59.1^{\prime \prime} \mathrm{N} \\
98^{\circ} 25^{\prime} 31.4^{\prime \prime} \\
\text { W }\end{array}$ & $\begin{array}{l}\text { Urban area with high population density (60,040 inhabitants), } 36 \text { medium-sized } \\
\text { companies, and } 3265 \text { commercial establishments }\end{array}$ \\
\hline 3 & Villa Alta & $\begin{array}{l}19^{\circ} 17^{\prime} 75.8^{\prime \prime} \mathrm{N} \\
98^{\circ} 10^{\prime} 1.6^{\prime \prime} \mathrm{W}\end{array}$ & $\begin{array}{l}\text { Rural area with industrial manufacturing activity, agricultural production of grains and } \\
\text { vegetables, an industrial park and petrochemical complex, and } 5974 \text { inhabitants. }\end{array}$ \\
\hline
\end{tabular}

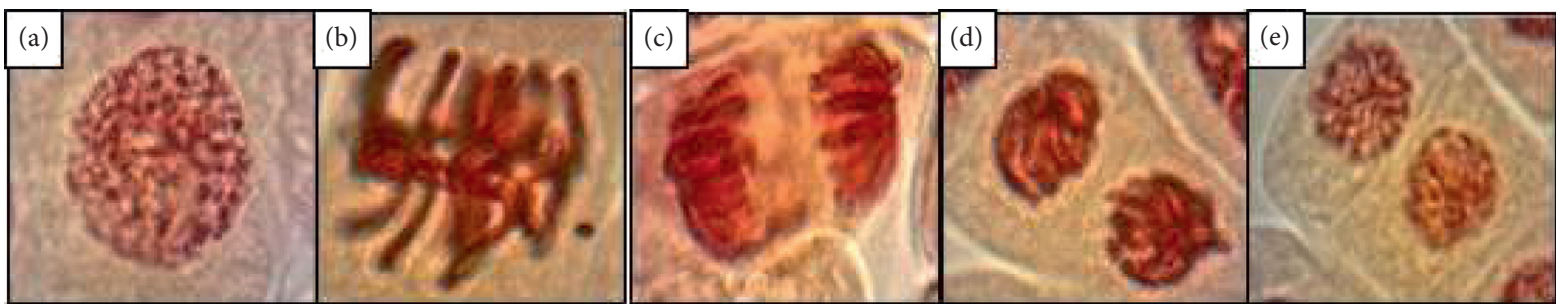

Figure 2: Meristems of Allium cepa exposed to water from the Atoyac River in the sampling zones. (a) Prophase; (b) Metaphase; (c) Anaphase; (d) Telophase; (e) Cytokinesis.

\section{Results}

Table 2 presents the analysis of variance of 14 physicochemical parameters evaluated in the 3 sampling zones of the Atoyac River. The analyses showed significant differences in $35.7 \%$ and $85.7 \%$ of the parameters evaluated in zones 2 and 3 , respectively, in relation to zone 1 . The values of $\mathrm{BOD}_{5}$ and COD increased $209 \%$ and $752 \%$, respectively, in zone 3 in relation to zone 1 , and the amount of DO decreased 11 times in relation to zone 1. A significant increase in the concentration of TM was observed in in zone 3.. For example, mercury levels were 600 times higher in zone 3 than in zone 1. Regarding VOCs, the results showed that $100 \%$ of the parameters quantified in zone 3 were significantly higher than in zones 1 and 2. Benzene and trichloroethylene were 25.5 and 23.3 times higher, respectively, than in zone 1. These results indicate that river pollution is generalized in the municipality, but it is not the same at all points, and zone 3 presents the highest degree of water pollution due to the strong influence of anthropic activities in the area, most of which are of industrial origin.

Table 3 shows the analysis of variance of the mitotic index and cell population phases in the apical meristems of Allium cepa L. exposed for 120 hours to different concentrations of water from the Atoyac River in the 3 study zones. The mitotic index decreased in the treatments of zones 2 and 3. The most significant decreases occurred in the treatments of $50 \%$ and $100 \%$ of zone 3 with a decrease of $23.1 \%$ and 
TABLE 2: Values of physicochemical parameters, toxic metals, and volatile organic compounds of water samples from different sites of the Atoyac River.

\begin{tabular}{lccc}
\hline Parameters & & Sampling area & \multicolumn{1}{c}{ Z3 } \\
\hline $\mathrm{pH}(\mathrm{UpH})$ & $\mathrm{Z} 1$ & $4.9 \pm 0.5^{\mathrm{a}}$ & $5.2 \pm 0.4$ \\
$\mathrm{Ec}(\mathrm{mS})$ & $6.5 \pm 0.2^{\mathrm{a}}$ & $0.246 \pm 0.13^{\mathrm{a}}$ & $0.310 \pm 0.23^{\mathrm{b}}$ \\
$\mathrm{TUB}(\mathrm{NTU})$ & $0.143 \pm 0.02^{\mathrm{a}}$ & $208 \pm 3^{\mathrm{b}}$ & $237.6 \pm 3^{\mathrm{b}}$ \\
$\mathrm{COD}\left(\mathrm{mgL}^{-1}\right)$ & $145.6 \pm 2^{\mathrm{a}}$ & $189 \pm 4^{\mathrm{b}}$ & $192 \pm 6^{\mathrm{b}}$ \\
$\mathrm{BOD}\left(\mathrm{mgL}^{-1}\right)$ & $62 \pm 3^{\mathrm{a}}$ & $34.24 \pm 0.94^{\mathrm{b}}$ & $58.79 \pm 0.52^{\mathrm{b}}$ \\
$\mathrm{DO}\left(\mathrm{mgL}^{-1}\right)$ & $6.95 \pm 0.28^{\mathrm{a}}$ & $1.1 \pm 0.3^{\mathrm{b}}$ & $0.5 \pm 0.2^{\mathrm{b}}$ \\
$\mathrm{As}\left(\mathrm{mgL}^{-1}\right)$ & $5.5 \pm 0.6^{\mathrm{a}}$ & $0.7^{\mathrm{a}}$ & $1.7^{\mathrm{b}}$ \\
$\mathrm{Cd}\left(\mathrm{mgL}^{-1}\right)$ & $0.4^{\mathrm{a}}$ & $0.4^{\mathrm{a}}$ & $0.9^{\mathrm{b}}$ \\
$\mathrm{Cu}\left(\mathrm{mgL}^{-1}\right)$ & $0.3^{\mathrm{a}}$ & $4.8^{\mathrm{a}}$ & $8.8^{\mathrm{b}}$ \\
$\mathrm{Cr}\left(\mathrm{mgL}^{-1}\right)$ & $3.8^{\mathrm{a}}$ & $1.5^{\mathrm{a}}$ & $7.5^{\mathrm{b}}$ \\
$\mathrm{Hg}\left(\mathrm{mgL}^{-1}\right)$ & $1.3^{\mathrm{a}}$ & $0.2^{\mathrm{b}}$ & $1.2^{\mathrm{c}}$ \\
$\mathrm{C}_{6} \mathrm{H}_{6}\left(\mu \mathrm{gL}^{-1}\right)$ & $0.002^{\mathrm{a}}$ & $0.3^{\mathrm{a}}$ & $0.5^{\mathrm{b}}$ \\
$\mathrm{CHCl}_{3}\left(\mu \mathrm{gL}^{-1}\right)$ & $0.02^{\mathrm{a}}$ & $0.05^{\mathrm{a}}$ & $0.30^{\mathrm{b}}$ \\
$\mathrm{C}_{2} \mathrm{HCl}_{3}\left(\mu \mathrm{gL}^{-1}\right)$ & $0.05^{\mathrm{a}}$ & $0.03^{\mathrm{a}}$ & $0.70^{\mathrm{b}}$ \\
\hline
\end{tabular}

pH: hydrogen potential; Ec: electrical conductivity; TUB: turbidity; COD: chemical oxygen demand; BOD $_{5}$ : biochemical oxygen demand; DO: dissolved oxygen; As: arsenic; $\mathrm{Cd}$ : cadmium; Cr: chromium; $\mathrm{Hg}$ : mercury; $\mathrm{C}_{6} \mathrm{H}_{6}$ : benzene; $\mathrm{CHCl}_{3}$ : chloroform; $\mathrm{C}_{2} \mathrm{HCl}_{3}$ : trichloroethylene; $\mathrm{Z1}$ : study area 1; $\mathrm{Z2}$ : study area 2; Z3: study area 3. Different literals $(\mathrm{a}, \mathrm{b}$, and $\mathrm{c})$ indicate a significant difference between study zones $(p<0.05)$.

TABle 3: Effect of Atoyac River water on mitotic index and phase indices in meristems of A. cepa after 120 hours of exposure.

\begin{tabular}{|c|c|c|c|c|c|c|}
\hline \multirow{2}{*}{ Zone } & \multirow{2}{*}{ Group } & \multirow{2}{*}{$\mathrm{MI}(\mathrm{M} \pm \mathrm{SD})$} & \multicolumn{4}{|c|}{$\%$ Phase index $(\mathrm{M} \pm \mathrm{SD})$} \\
\hline & & & PI & MeI & AI & $\mathrm{TI}$ \\
\hline \multirow{4}{*}{$\mathrm{Z} 1$} & $\mathrm{C}$ & $54.3 \pm 0.5^{\mathrm{a}}$ & $91.5 \pm 1.4^{\mathrm{a}}$ & $3.5 \pm 0.4^{\mathrm{a}}$ & $3.1 \pm 0.4^{\mathrm{a}}$ & $2.0 \pm 0.6^{\mathrm{a}}$ \\
\hline & $25 \%$ & $53.6 \pm 0.9^{\mathrm{a}}$ & $91.1 \pm 0.5^{\mathrm{a}}$ & $3.9 \pm 0.2^{\mathrm{a}}$ & $3.4 \pm 0.4^{\mathrm{a}}$ & $1.7 \pm 0.3^{\mathrm{a}}$ \\
\hline & $50 \%$ & $51.6 \pm 0.9^{\mathrm{a}}$ & $91.5 \pm 1.3^{\mathrm{a}}$ & $4.1 \pm 0.2^{\mathrm{a}}$ & $2.7 \pm 0.8^{\mathrm{a}}$ & $1.8 \pm 0.4^{\mathrm{a}}$ \\
\hline & $100 \%$ & $54.3 \pm 1.1^{\mathrm{a}}$ & $93.1 \pm 2.1^{\mathrm{a}}$ & $2.7 \pm 0.7^{\mathrm{a}}$ & $2.6 \pm 0.7^{\mathrm{a}}$ & $1.5 \pm 0.8^{\mathrm{a}}$ \\
\hline \multirow{4}{*}{$\mathrm{Z} 2$} & $\mathrm{C}$ & $53.8 \pm 0.5^{\mathrm{a}}$ & $92.2 \pm 1.5^{\mathrm{a}}$ & $3.1 \pm 0.3^{\mathrm{a}}$ & $2.9 \pm 0.7^{\mathrm{a}}$ & $1.8 \pm 0.6^{\mathrm{a}}$ \\
\hline & $25 \%$ & $54.3 \pm 0.2^{\mathrm{a}}$ & $91.7 \pm 1.7^{\mathrm{a}}$ & $3.4 \pm 0.1^{\mathrm{a}}$ & $2.3 \pm 0.4^{\mathrm{a}}$ & $1.9 \pm 0.3^{\mathrm{a}}$ \\
\hline & $50 \%$ & $46.5 \pm 1.4^{\mathrm{b}}$ & $94.2 \pm 1.3^{\mathrm{a}}$ & $2.2 \pm 0.2^{\mathrm{b}}$ & $2.1 \pm 0.7^{\mathrm{a}}$ & $1.5 \pm 0.4^{\mathrm{a}}$ \\
\hline & $100 \%$ & $42.0 \pm 0.7^{\mathrm{c}}$ & $96.3 \pm 0.5^{\mathrm{b}}$ & $1.5 \pm 0.3^{\mathrm{b}}$ & $1.6 \pm 0.2^{\mathrm{a}}$ & $0.6 \pm 0.4^{\mathrm{a}}$ \\
\hline \multirow{4}{*}{$\mathrm{Z3}$} & $\mathrm{C}$ & $54.1 \pm 0.3^{\mathrm{a}}$ & $93.6 \pm 0.4^{\mathrm{a}}$ & $3.1 \pm 0.3^{\mathrm{a}}$ & $1.9 \pm 0.2^{\mathrm{a}}$ & $1.4 \pm 0.2^{\mathrm{a}}$ \\
\hline & $25 \%$ & $43.8 \pm 0.7^{\mathrm{b}}$ & $95.0 \pm 0.6^{\mathrm{a}}$ & $2.3 \pm 0.2^{\mathrm{a}}$ & $1.7 \pm 0.3^{\mathrm{a}}$ & $1.1 \pm 0.2^{\mathrm{a}}$ \\
\hline & $50 \%$ & $41.6 \pm 0.8^{\mathrm{c}}$ & $96.0 \pm 1.2^{\mathrm{b}}$ & $1.4 \pm 0.4^{\mathrm{b}}$ & $1.7 \pm 0.2^{\mathrm{a}}$ & $1.0 \pm 0.6^{\mathrm{a}}$ \\
\hline & $100 \%$ & $0.0 \pm 0$ & $0.0 \pm 0$ & $0.0 \pm 0$ & $0.0 \pm 0$ & $0.0 \pm 0$ \\
\hline
\end{tabular}

C: concentration; MI: mitotic index; PI: prophase index; MeI: metaphase index; AI: anaphase index; TI: telophase index; M: mean value; SD: standard deviation; Z1: study zone 1; Z2: study zone 2; Z3: study zone 3. Different literals ( $a, b$, and $c$ ) indicate there is a significant difference between study zones $(p<0.05)$. The $100 \%$ treatment in $\mathrm{Z} 3$ did not show root development.

$100 \%$, respectively, in relation to the control group. These results show that there is a concentration-dependent antimitotic effect of the pollutants present in the different study zones.

In relation to the PI, a tendency to increase was observed in the 3 sampling zones as the concentration of contaminants increased. The greatest increase was observed in the $100 \%$ treatment in zone 2 with $4.4 \%$ with respect to the control. The MeI showed a tendency to decrease in each treatment of the sampling zones with respect to the concentration of the treatments. The greatest decrease was observed in the $50 \%$ treatment in zone 3 with a decrease of $54.8 \%$ with respect to the control group. Regarding the anaphase and telophase indices, no significant variations were observed in any of the experimental groups in the sampling zones. This indicates that the cytotoxic effect of toxic metals and volatile organic compounds does not affect all metaphase stages in the Allium cepa L. meristem cell population.

The correlation between the concentration of 8 parameters of TM and VOCs in the $100 \%$ water samples of the study area with respect to the cytotoxic effect of Allium cepa L. meristems (Table 4) showed that there is a high negative correlation between the concentration of TM and VOCs in relation to the frequency of cells in the mitosis stage. As the concentration of TM and VOCs increased, the mitotic index of the apical meristem cell population decreased. Copper was the element that presented the greatest cytotoxic effect with respect to its concentration. For example, it had a $22 \%$ and $11 \%$ greater antimitotic effect with respect to 
TABLE 4: Correlation matrix of toxic metals, volatile organic compounds, and mitotic index.

\begin{tabular}{lccccccc}
\hline & $\mathrm{As}$ & $\mathrm{Cd}$ & $\mathrm{Cr}$ & $\mathrm{Cu}$ & $\mathrm{Hg}$ & $\mathrm{C}_{6} \mathrm{H}_{6}$ & $\mathrm{CHCl}_{3}$ \\
\hline $\mathrm{Cd}$ & 0.994 & & & & & & \\
$\mathrm{Cr}$ & 0.975 & 0.963 & & & & & \\
$\mathrm{Cu}$ & 0.973 & 0.990 & 0.917 & & & & \\
$\mathrm{Hg}$ & 0.960 & 0.931 & 0.987 & 0.872 & & & \\
$\mathrm{C}_{6} \mathrm{H}_{6}$ & 0.937 & 0.913 & 0.989 & 0.848 & 0.992 & & \\
$\mathrm{CHCl}_{3}$ & 0.967 & 0.954 & 0.999 & 0.905 & 0.986 & 0.992 & \\
$\mathrm{C}_{2} \mathrm{HCl}_{3}$ & 0.933 & 0.908 & 0.987 & 0.843 & 0.989 & 1.000 & 0.991 \\
$\mathrm{MI}$ & -0.963 & -0.984 & -0.899 & -0.999 & -0.851 & -0.824 & -0886 \\
\hline
\end{tabular}

Correlation matrix: Pearson's coefficient. Correlation significance: $p<0.05$.

trichloroethylene and chromium. It is clearly observed that the greatest antimitotic effect is induced by TM and not by VOCs.

\section{Discussion}

Worldwide, rivers are exposed to enormous discharges of urban and domestic wastewater, as well as agricultural runoff, which upon reaching the ecosystem form complex mixtures of pollutants with toxic metals, volatile organic compounds, dyes, acids, bases, etc. This contamination in rivers and bodies of water is directly influenced by the type of anthropogenic activities that take place in the area where they are located and conditions their contaminant profile [21]. Seventy-two percent of the industries that operate in the localities of the study area belong to the metalworking and textile sectors. Because of this, the largest proportion of pollutants dumped on the site are toxic metals, dyes, acids, bases, chlorine, and peroxides. In addition, other types of industries present in the area to a lesser extent, representing $12 \%$, such as printing, chemical, and petroleum derivatives producers [22] are primary sources of VOCs, which are organic chemical substances whose base is carbon and evaporate at ambient temperature and pressure in the rivers, generating vapors that enter the air, reaching the inhabited areas near the river [9]. The water samples that were collected come from 3 areas with different anthropogenic activities. Zone 1 presents a contribution mainly from agricultural and urban runoff, zone 2 includes urban wastewater, and zone 3 includes urban, industrial, and agricultural wastewater. All the samples induced cytotoxicity that was verified by the inhibition in the cell division process and consequently in the growth of roots. Because of this, most of the population is exposed to a high variety and quantity of substances that put their health at risk of cytotoxicity and that is dependent on the concentration of pollutants emitted in the area.

Our results are consistent with the theory that the contamination of the Atoyac River in the 3 selected sampling points is generalized because the physicochemical evaluation indicated the presence of organic matter, turbidity, TM, and VOCs exceeding the maximum limits allowed by the NOM. Additionally, the results partially agree with what was reported by Mokarram et al. [23], Chamarra and Koichi [24], Brito et al. [25], and Peng et al. [26] who determined that changes in water quality due to higher concentrations of pollutants such as organic matter and TM are associated with the increase in anthropogenic activities due to rapid urbanization and increased industrial activity, since the discharges of these effluents do not receive adequate treatment before being discharged and therefore do not comply with local official environmental standards. Few works at a global level have carried out the evaluation of VOCs in aquatic ecosystems. Our results partially agree with those of Montero et al. [9] and Sandoval et al. [27] who identified chloroform, benzene, xylene, and toluene in the Atoyac River, and their results were below those recorded in the present investigation.

This behaviour in water quality in rivers globally is mainly due to the intense industrialization that began in the 1970s with the imposition of the neoliberal model [28] and continues to this day, which has allowed the limitation of the state and public spending in favor of the private sector [29], coupled with lax laws, and permissibility of authorities has resulted in high pollution with toxic agents in the world's water bodies. It is important to clarify that the results of this study have contributed to determine pollutants such as VOCs that have been little evaluated; however, the presence of certain types of toxic agents will depend on the socioeconomic environment and the spatial and temporal distribution of pollutant sources. The evaluation of the physicochemical quality of water resources is a subject that has been addressed since the last century; for this purpose, several studies have been carried out in the world, such as those conducted by Vega et al. in Spain [30], Apsite and Klavins in Latvia [31], and Ouyang et al. in the United States [32], which have quantified main parameters to determine the water quality, mainly the quantity of organic matter such as BOD, COD, TOC, nitrates, nitrites, phosphates, salinity, minerals ( $\mathrm{Mg}$ and $\mathrm{Ca}$ ), and toxic metals. Even more studies are currently being conducted to evaluate new pollutants such as the so-called emerging pollutants, among which are pharmaceutical waste [33], microplastics [26, 34], and cosmetics [35]. Unfortunately, worldwide and particularly in Mexico, there are few research works that include the determination of VOCs in the physicochemical analysis when determining water quality in rivers. The importance of evaluating the presence and quantity of VOCs in river water quality analysis is because some VOCs such as benzene, chloroform, and ethyl tetrachloride have been classified by the WHO as type I carcinogens. It is therefore necessary to carry out more quantitative assessments of pollutant 
mixtures containing these types of compounds to help authorities examine the potential health hazard to avoid or at least reduce it.

The pollutant mixture of TM and VOCs in the waters of the Atoyac River induces antimitotic effects and alterations in the phase index in the cells of organisms exposed to this mixture and can cause mutations in their genetic material and lead to diseases such as cancer. Our results agree with the theory because the analysis of $\mathrm{Al}$ lium cepa L. meristem cells exposed to water samples from the Atoyac River showed inhibition in the mitosis process of the cell population. This could be attributed to VOCs and TM, which promote the synthesis of nuclear protein kinase (WEE1) responsible for phosphorylating and inactivating the Cdk1 enzyme preventing its association with cyclin B protein and thus inhibiting the activity of mitosis-promoting factor (MPF) $[36,37]$. The results of this research agree with those of other investigations $[38,39]$ that observed a decrease of MI dependent on the increase of the dose of their treatments with respect to time by the increase of nanoparticles and glyphosate, respectively, in the medium. The prophase index (PI) also showed alterations in the cell population of exposed $\mathrm{Al}$ lium cepa meristems because increases were observed in the groups with higher concentrations of TM and VOCs. These results demonstrate the cytotoxicity produced by TM and VOCs that probably block the Cdk and cyclin A-B complexes, which are responsible for initiating the condensation of genetic material as well as activating proteins called condensins that are responsible for carrying out the polymerization of microtubules for the formation of the achromatic spindle, which enables the normal transition of dividing cells from the prophase stage to the metaphase and anaphase stages [40]. The metaphase index (MI) showed significant differences in the higher concentration treatments in sampling zones 2 and 3 . This decrease is related to the concentrations of TM and VOCs, which exceed the maximum limits allowed by the Mexican Official Standards and would be acting directly on the center of microtubule organization (COMT) that is responsible for inducing the assembly of the mitotic spindle, so that when this process is affected, the passage from the prophase stage to the metaphase stage is prevented $[41,42]$; this coincides with the results obtained in relation to the decrease in the number of cells in metaphase. From the results obtained from the different treatments for the anaphase index (AI) and telophase index (TI), nonsignificant concentration-dependent decreases were observed for the treatments in the 3 sampling zones. This indicates that the concentrations of TM and VOCs moderately interfere with the synthesis of the anaphase promoter complex (APC), allowing the activity of proteins called cohesins and catastrophins, which are responsible for carrying out the chromatid separation process so that cells can transit from anaphase to telophase. With respect to the nonsignificant decrease in TI, this is due to the imbalance observed in the PI, since the increase in the number of cells in the prophase stage means that the mitosis process decreases and is ultimately reflected in the decrease in TI $[36,43,44]$. The results obtained from the AI of this research partially agree with those reported by Liman et al. [45] who evaluated the cytogenetic and genotoxic effects of rosmaniric acid on Allium cepa L. roots at different times and concentrations and did not observe a pattern that could explain the increase or decrease of cells in anaphase relative to his control group. Additionally, these results agree with those reported by Quispe et al. [46] who evaluated the effects of potassium sorbate at different concentrations and exposure time on the cell cycle in root meristems of Allium cepa L. and observed that TI percentages decreased as concentration and exposure time increased. The cytotoxic evaluation of contaminant mixtures in aquatic ecosystems is complicated due to the quantity and variety of compounds that may be present; however, they are not limited to a single type of zone or contaminant. The use of plants as biomodels to assess the cytotoxic potential of contaminated water bodies is relatively new, and most cytotoxic research has focused on assessing the damage of individually toxic agents such as aluminium [47], herbicides [48], pesticides [49], and hypochlorite [50], among others. Unfortunately, in nature, organisms are not exposed to only one type of contaminant, so it is essential to carry out evaluations of the cytotoxic effects of mixtures of contaminants in natural environments, for which different types of plants have been used as biomodels such as Vicia faba L., Pseudokirchneriella subcapitata, and Lactuca sativa L. [51]. Allium cepa L. has been used to evaluate the cytotoxicity of medicinal plant extracts, xenobiotics, herbicides, nanoparticulates, fertilizers, preservatives, etc. Few ecotoxicological investigations of water bodies such as rivers have used Allium cepa L. to determine its cytotoxic potential, such as those carried out in Malaysia [52], Brazil [53], and Colombia [54]. In Mexico, research to evaluate the cytotoxic potential of contaminated water in rivers is very scarce. Therefore, it is important to perform this type of evaluation of contaminated river water with biomodels to correlate the potential health damage that this type of contamination can induce in biological systems.

According to the dose-response theory of the kinetic toxic effect, we infer that the higher concentration of contaminants is a factor that directly influences the cytotoxic effects of the cell population in the roots of Allium cepa. Our findings corroborate that the antimitotic effect depends on the concentration of TM and VOCs. The results of this research agree with those reported by Batista et al. [5], Bianchi et al. [6], and Hilario et al. [53], who demonstrated that there is a direct correlation between the concentration of pollutants in rivers and mitotic index parameters. TM and VOCs upon entering the cells of the organism have a great capacity to bind to organic molecules $[55,56]$, and their effects depend on the reactions with ligands such as sulfhydryl groups, amino radicals, phosphate, carboxyl, and hydroxyl. Then, if the proportion of pollutants is greater, there will be a greater amount of ligands that would react resulting in greater response to cell damage. Although it is difficult to evaluate the cytotoxic effect of contaminant mixtures due to the synergism or antagonism effects that may 
occur with contaminants, it is advisable to perform this type of study in natural environments because that is how living beings are exposed in real life to real environmental contaminant mixtures [57].

\section{Conclusions}

This research demonstrated that the contaminant mixture of toxic metals and volatile organic compounds in a river has the capacity to induce aneugenic effects in the apical meristem cells of Allium cepa L. and may have a strong negative correlation because as the concentration of contaminants increases, the mitotic index decreases. Therefore, additional research is needed to determine the damage caused by each pollutant, and based on this, governmental decisions should be made to mitigate the environmental impacts on rivers caused by different anthropogenic activities.

\section{Data Availability}

The experimental data used to support the findings of this study are available upon request from the corresponding author.

\section{Conflicts of Interest}

The authors have no conflicts of interest to declare.

\section{Acknowledgments}

Andrés Estrada Rivera would like to thank Consejo Nacional de Ciencia y Tecnología (CONACYT) for the scholarship (601562). The costs to publish in open access were covered by Programa para el Desarrollo Profesional Docente (PRODEP) of the Secretaria de Educación Pública de México (SEP). This research was funded by VIEP_BUAP.

\section{References}

[1] S. Abraham, M. Oviyanti, S. Rija, T. Emma, H. Muhammad, and M. Asep, "Analysis of the water quality at Cipeusing river, Indonesia using the pollution index method," Acta Ecologica Sinica, vol. 41, no. 3, pp. 177-182, 2021.

[2] United Nations, Water Statistics, New York, NY, USA, 2019.

[3] Y. Yu, Y. Li, Z. Shen et al., "Occurrence and possible sources of organochlorine pesticides (OCPs) and polychlorinated biphenyls (PCBs) along the Chao River, China," Chemosphere, vol. 114, pp. 136-143, 2014.

[4] E. Arusievicz, C. Torres, L. Gavronski, T. Nunes, N. Oliveira, and J. Silva, "Genotoxic assessment on river water using different biological systems," Chemosphere, vol. 84, no. 1, pp. 47-53, 2011.

[5] N. J. C. Batista, A. A. de Carvalho Melo Cavalcante, M. G. de Oliveira et al., "Genotoxic and mutagenic evaluation of water samples from a river under the influence of different anthropogenic activities," Chemosphere, vol. 164, no. 1, pp. 134-141, 2016.

[6] J. Bianchi, E. L. Espindola, and M. A. Marin-Morales, "Genotoxicity and mutagenicity of water samples from the Monjolinho River (Brazil) after receiving untreated effluents," Ecotoxicology and Environmental Safety, vol. 74, no. 1, pp. 826-833, 2016.
[7] D. Tian, W. Zheng, G. He et al., "Predicting cytotoxicity of complex mixtures in high cancer incidence regions of the Huai River Basin based on GC-MS spectrum with partial least squares regression," Environmental Research, vol. 137, pp. 391-397, 2015.

[8] R. D. Montero-Montoya, R. López-Vargas, A. Méndez-Serrano et al., "Increased micronucleus frequencies in reticulocytes of children exposed to industrial pollution: oxidative stress and the OGG1 S326C polymorphism," Mutation Research: Genetic Toxicology and Environmental Mutagenesis, vol. 853, Article ID 503170, 2020.

[9] R. Montero, L. Serrano, A. Araujo et al., "Increased cytogenetic damage in a zone in transition from agricultural to industrial use: comprehensive analysis of the micronucleus test in peripheral blood lymphocytes," Mutagenesis, vol. 21, no. 5, pp. 335-342, 2006.

[10] P. García, D. Linhares, F. Amaral, and A. Rodrigues, "Exposure of thermoelectric power plant workers to volatile organic compounds from fuel oil: genotoxic and cytotoxic effects on oral epithelial cells," Investigación de mutaciones/ Toxicología genética y mutagénesis ambiental, vol. 747, no. 2, pp. 197-202, 2012.

[11] R. Gminski, T. Tang, and V. Mersch-Sundermann, "Cytotoxicity and genotoxicity in human lung epithelial A549 cells caused by airborne volatile organic compounds emitted from pine wood and oriented strand boards," Toxicology Letters, vol. 196, no. 1, pp. 33-41, 2010.

[12] C. Bocchi, C. Bazzini, F. Fontana, G. Pinto, A. Martino, and F. Cassoni, "Characterization of urban aerosol: seasonal variation of mutagenicity and genotoxicity of PM 2.5 , PM 1 and semi-volatile organic compounds," Mutation Research: Genetic Toxicology and Environmental Mutagenesis, vol. 809, no. 1, pp. 16-23, 2016.

[13] S. T. Matsumoto, M. S. Mantovani, M. I. A. Malaguttii, A. L. Dias, I. C. Fonseca, and M. A. Marin-Morales, "Genotoxicity and mutagenicity of water contaminated with tannery effluents, as evaluated by the micronucleus test and comet assay using the fish Oreochromis niloticus and chromosome aberrations in onion root-tips," Genetics and Molecular Biology, vol. 29, no. 1, pp. 148-158, 2006.

[14] Government of the State of Puebla National Institute of Geography and Informatics, Statistical and Geographic Yearbook of Puebla, Government of the State of Puebla, Statistical and Geographic Yearbook of Puebla 2017, 2017, http://internet. contenidos.inegi.org.mx/contenidos/Productos/prod_serv/conte nidos/espanol/bvinegi/productos/nueva_estruc/anuarios_2017/7 02825094973.pdf.

[15] National Water Commission of Mexico (NWC), General Coordination of the National Meteorological Service, Ministry of Environment and Natural Resources, Mexico City, Mexico, 2017.

[16] Meteorology Statal Agency, http://www.aemet.es/es/portada, 2021.

[17] Mexican Standard: NMX-AA-121/1-SCFI-2008. Water Analysis - Epicontinental, Coastal and Marine Natural Waters - Sampling. http://legismex.mty.itesm.mx/normas/AA/ proy0909/proy-nmx-aa-121-1-scfi08.pdf.

[18] G. Fiskesjö, “The Allium test as a standard in environmental monitoring," Hereditas, vol. 102, no. 1, pp. 99-112, 1985.

[19] Mexican Standard: http://legismex.mty.itesm.mx/normas/aa/ aa103-2012_12.pdf NMX-AA-103-SCFI-2006. Residues-Determination of Volatile Organic Compounds by Gas Chromatography Coupled to a Mass Spectrometer in Extraction Products of Toxic Constituents. 
[20] Mexican Standard: https://www.dof.gob.mx/nota_detalle. php codigo $=5464459 \&$ fecha $=07 / 12 / 2016 \quad$ NMX-AA-051SCFI-2006. Measurement of Metals by Atomic Absorption in Natural, Drinking, Residual and Treated Residual Waters..

[21] V. Esser, M. Buchty-Lemke, P. Schulte, L. S. Podzun, and F. Lehmkuhl, "Signatures of recent pollution profiles in comparable central European rivers-examples from the international River Basin District Meusefiles in comparable central European rivers-examples from the international River Basin District Meuse," Catena, vol. 193, no. 2020, Article ID 104646, 2020.

[22] National Institute of Statistics, Geography and Informatics Mexico, National Directory of Economic Activities (NDEA), National Institute of Statistics Geography and Informatics (NISGI), United Nations, New York, NY, USA, 2020.

[23] M. Mokarram, A. Saber, and V. Sheykhi, "Effects of heavy metal contamination on river water quality due to release of industrial effluents," Journal of Cleaner Production, vol. 277, Article ID 123380, 2020.

[24] P. Chamarra and Y. Koichi, "Impact of population growth on the water quality of natural water bodies," Sustentability, vol. 9, no. 8, p. 1405, 2017.

[25] E. M. S. Brito, M. De la Cruz Barrón, C. A. Caretta et al., "Impact of hydrocarbons, PCBs and heavy metals on bacterial communities in Lerma River, Salamanca, Mexico: investigation of hydrocarbon degradation potential," The Science of the Total Environment, vol. 521-522, pp. 1-10, 2015.

[26] H. Peng, Q. Su, P. Thiam, and T. Nv, "Changes in water quality during rapid urbanization in the Shenzhen River Basin: an integrated view of socioeconomic and infrastructure development," Sustentability, vol. 6, no. 10, pp. 7433-7451, 2014.

[27] A. Sandoval, G. Pulido, S. Monks, A. Gordillo, and E. Villegas, "Physicochemical, microbiological and toxicological evaluation of the environmental degradation of the Atoyac River, México," Interciencia, vol. 34, no. 12, pp. 880-887, 2009.

[28] J. Vallejo Román, “Talleres de mezclilla y transformaciones sociambientales en un municipio rural. El caso de Tepetitla de Lardizábal, Tlaxcala, México," Sociedad y Ambiente, vol. 11, no. 11, pp. 68-91, 2016.

[29] T. Boas and J. Gans, "Neoliberalism: from new liberal philosophy to anti-liberal slogan," Comparative international development studies, vol. 44, no. 1, pp. 137-161, 2009.

[30] M. Vega, R. Pardo, E. Barrado, and L. Debán, “Assessment of seasonal and polluting effects on the quality of river water by exploratory data analysis," Water Research, vol. 32, no. 12, pp. 3581-3592, 1998.

[31] E. Apsite and M. Klavins, "Evaluation of COD and color changes in Latvian rivers over the last twenty years," Medio Ambiente Internacional, vol. 24, no. 5, pp. 637-643, 1998.

[32] Y. Ouyang, "Evaluation of river water quality monitoring stations by principal component analysis," Water Research, vol. 39, no. 12, pp. 2621-2635, 2005.

[33] J. Kwon, S. Hun, H. Ran, and S. Ju, "Temporal-spatial variation and environmental risk assessment of pharmaceuticals in tributaries of the Han River watershed, South Korea," The Science of the Total Environment, vol. 741, Article ID 140486, 2020.

[34] A. A. Horton, M. D. Jürgens, E. Lahive, P. M. van Bodegom, and M. G. Vijver, "The influence of exposure and physiology on microplastic ingestion by the freshwater fish Rutilus rutilus (roach) in the River Thames, UK," Environmental Pollution, vol. 236, pp. 188-194, 2018.
[35] N. A. Vita, C. A. Brohem, A. D. P. M. Canavez et al., "Parameters for assessing the aquatic environmental impact of cosmetic products," Toxicology Letters, vol. 287, pp. 70-82, 2018.

[36] O. Timothy, M. Idu, D. I. Olorunfemi, and O. OvuakporieUvo, "Cytotoxic and genotoxic properties of leaf extract of Icacina trichantha Oliv," South African Journal of Botany, vol. 91, pp. 71-74, 2014.

[37] A. Yadav, A. Raj, D. Purchase, L. F. R. Ferreira, G. D. Saratale, and R. N. Bharagava, "Phytotoxicity, cytotoxicity and genotoxicity evaluation of organic and inorganic pollutants rich tannery wastewater from a Common Effluent Treatment Plant (CETP) in Unnao district, India using Vigna radiata and Allium cepa," Chemosphere, vol. 224, pp. 324-332, 2019.

[38] O. Herrero, J. M. Pérez Martín, P. Fernández Freire, L. Carvajal López, A. Peropadre, and M. J Hazen, "Toxicological evaluation of three contaminants of emerging concern by use of the Allium cepa test," Mutation Research, vol. 743, no. 1-2, pp. 20-24, 2012.

[39] S. Salazar and J. Quintero, "Cytotoxic evaluation of glyphosate, using Allium cepa $\mathrm{L}$ as bioindicator," The Science of the Total Environment, vol. 700, no. 1, Article ID 134452, 2020.

[40] P. K. Hepler and J. M. Hush, "Behavior of microtubules in living plant cells," Plant Physiology, vol. 112, no. 2, pp. 455-461, 1996.

[41] N. Andrioli and M. Mudry, "Cytological and cytogenetic effects induced by thiabendazole on allium cepa root meristems," Journal of basic and applied genetics, vol. 22, no. 2, pp. 17-23, 2011.

[42] E. Otiniano, Effect of Three Concentrations of Hydroalcoholic Extract of Citrus Limon on the Cell Cycle in Root Meristems of Allium cepa L, Universidad Naciona de Trujillo Facultad de Ciencias Biologicas, Trujillo, Peru, 2014, https://dspace.unitru. edu.pe/bitstream/handle/UNITRU/4353/Otiniano\%20Matos,\% 20Arely\%20Estela.pdf?sequence $=1$ \&isAllowed $=y$.

[43] R. Beltrán and K. Gonza, "Cytotoxicity and genotoxicity of the waters of the Jequetepeque and Moche rivers through the environmental bioindicator Vicia faba L," Scientia Agropecuaria, vol. 8, no. 3, pp. 203-213, 2017.

[44] J. Rodríguez, C. Barazorda, and L. Pollack, "Cytotoxicity and genotoxicity of gold nanoparticles synthesized by laser ablation on Allium cepa L. (Amaryllidaceae)," Arnaldoa, vol. 25, no. 3, pp. 1015-1026, 2018.

[45] R. Liman, İ. H. Ciğerci, and S. Gökçe, "Cytogenetic and genotoxic effects of Rosmaniric Acid on Allium cepa L. root meristem cells," Food and Chemical Toxicology, vol. 121, pp. 444-449, 2018.

[46] J. Quispe, J. Saldaña, T. Verde, and S. Valderrama, "Effect of Potassiu $\mathrm{m}$ Sorbate at different concentrations and exposure time on the cell cycle and the genetic material in root meristems of Allium cepa L "onion"," Encuentro científico internacional, vol. 7, no. 1, pp. 71-78, 2010.

[47] M. Li, R. Qin, W. Jiang, and D. Liu, "Cytogenetical effects of aluminum on root meristem cells of helianthus annuus 1," Botanical Sciences, vol. 93, no. 1, pp. 15-22, 2015.

[48] A. Berrocal, R. Blas, J. Flores, and M. Siles, "Evaluation of the mutagenic potential of biocides (vertimec and pentachloro) on onion," Revista Colombiana de Biotecnología, vol. 15, no. 1, pp. 17-27, 2013.

[49] J. Bianchi, T. C. Casimiro Fernandes, and M. A. MarinMorales, "Induction of mitotic and chromosomal abnormalities on Allium cepa cells by pesticides imidacloprid and sulfentrazone and the mixture of them," Chemosphere, vol. 144, no. 1, pp. 475-483, 2016. 
[50] L. A. Causil Vargas, J. L. Coronado, L. F. Verbel, M. F. Vega, K. A. Donado, and C. Pacheco, "Efecto citotóxico del hipoclorito de sodio $(\mathrm{NaClO})$, en células ápicales de raíces de cebolla (Allium cepa L.)," Revista Colombiana de Ciencias Hortícolas, vol. 11, no. 1, pp. 97-104, 2017.

[51] L. N. Biruk, J. Moretton, A. Fabrizio de Iorio et al., "Toxicity and genotoxicity assessment in sediments from the MatanzaRiachuelo river basin (Argentina) under the influence of heavy metals and organic contaminants," Ecotoxicology and Environmental Safety, vol. 135, no. 1, pp. 302-311, 2017.

[52] A. Akeem, M. Kamaruzaman, R. Selestin, and R. Vijay, "Genotoxicity assessment of water samples from the sungai dua River in pulau pinang, Malaysia, using the Allium cepa test," Tropical Life Sciences Research, vol. 22, no. 2, pp. 23-35, 2011.

[53] A. L. Hilario Garcia, C. A. Matzenbacher, M. S. Santos et al., "Genotoxicity induced by water and sediment samples from a river under the influence of brewery effluent," Chemosphere, vol. 169, no. 1, pp. 239-248, 2017.

[54] T. Cavadía, M. Roche, and R. Romero, "Estimation of the genotoxicity of the Sinú river through to bioassay with Allium cepa L in Montería, Córdoba-Colombia," Revista Bistua Facultad de Ciencias Basicas, vol. 16, no. 1, pp. 174-184, 2018.

[55] J. Navarro, A. Aguilar, and J. López, "Biochemical and genetic aspects of tolerance and accumulation of heavy metals in plants," Ecosystems, vol. 16, no. 2, pp. 10-25, 2007.

[56] Z. Pan, Y. Sun, Q. Liu et al., "Riverine microplastic pollution matters: a case study in the Zhangjiang River of Southeastern China," Marine Pollution Bulletin, vol. 159, Article ID 111516, 2020.

[57] A. Ramirez, "Cadmium toxicology current concepts to assess environmental or occupational exposure with biological indicators," Anales de la Facultad de Medicina, Universidad Nacional Mayor de San Marcos, vol. 63, no. 1, pp. 51-64, 2002. 